\title{
Corrigendum: 'n Navorsingstrategie vir missionale transformasie
}

\section{Authors:}

Cornelius J.P. Niemandt ${ }^{1}$ (D)

Jan F. Marais ${ }^{2}$ (D)

Willem J. Schoeman ${ }^{3}$ (D)

Pieter van der Walt ${ }^{2}$

Nico Simpson ${ }^{4}$ (D)

\section{Affiliations:}

${ }^{1}$ Department of Religion

Studies, University of

Pretoria, South Africa

${ }^{2}$ Faculty of Theology,

University Stellenbosch,

South Africa

${ }^{3}$ Department Practical

Theology, University of the

Free State, South Africa

${ }^{4}$ Bible Media, Wellington,

South Africa

Corresponding author:

Cornelius Niemandt,

nelus.niemandt@up.ac.za

Dates:

Published: 10 Dec. 2018

How to cite this article:

Niemandt, C.J.P., Marais, J.F.,

Schoeman, W.J., Van der

Walt, P. \& Simpson, N., 2018,

'Corrigendum: 'n

Navorsingstrategie vir

missionale transformasie',

Verbum et Ecclesia 39(1),

a1956. https://doi.

org/10.4102/ve.v39i1.1956

\section{Copyright:}

(C) 2018. The Authors.

Licensee: AOSIS. This work

is licensed under the

Creative Commons

Attribution License.

Scan this QR

code with your

smart phone or

mobile device

to read online.
In the author list of this article published earlier, Jan F. Marais's first name was unintentionally misprinted as 'Jacobus'. The correct first name is 'Jan'. The author sincerely apologises for any inconvenience caused. 